\title{
THE ANALYSIS OF EXPORT TRADE BETWEEN UKRAINE AND VISEGRAD COUNTRIES
}

\author{
L'udmila Nagyová, Monika Horáková, Serhiy Moroz, \\ Elena Horská, Zuzana Poláková
}

\section{Introduction}

The dynamic development of foreign trade is important for the stable economic position of each country. It can be considered as a confirmation of the actual efficiency of the national economy and its ability to be competitive in the global economic system. The growth of this trade is particularly essential for Ukraine, taking into account the crisis situation in the country. In this paper, we analyze main tendencies of export trade of Ukraine with Visegrad countries (Czech Republic, Hungary, Poland and Slovak Republic) and examine whether there is a relationship between the level of GDP and the volume of export activities between these countries.

It should be noted that various agreements were concluded between Ukraine and each country of the V4 group regarding economic and trade relations. These agreements made the business competitiveness, not only for Ukraine itself, higher. Even the V4 countries benefit from this cooperation. The principal sectors of economy are industry, agriculture and the area of scientific as well as technical cooperation.

Furthermore, all V4 countries are members of the European Union at present. Only the Slovak Republic also belongs to the Euro area (19 members in 2017). All V4 countries have advantages coming from being the EU members. Above all, they have financial benefits, such as using the finances from major Structural \& Investment Funds (each focused on several key priority areas), Grants or Contracts (European Commission, 2017a). Moreover, Horák, Prýmek, Prokop and Mišák (2015) highlight the benefits for Czech households which are subsidized by the program Green Premium from EU. This is a financial benefit for households and it has a positive impact on environment, too. In addition, Olinski, Szamrowski and Luty (2016) analyze the impact of EU-funds on small and medium-sized enterprises (SME) in Poland. On the contrary, Vojtovič (2016) points out the use of Structural Funds for SMEs in Slovakia.

Nevertheless, being part of a larger economic or political group does not always mean a positive economic impact on a particular country or region. Zdražil and Applová (2016) present in their study the disparity of benefits when individual V4 regions enter the EU. The final GDP indicator per capita reflected the initial negative results in the areas of productivity and employment. That is the reason why the Ukraine-EU Deep and Comprehensive Free Trade Agreement (DCFTA) regulate many aspects of business cooperation between the countries. SMEs in Ukraine even have access to the financial support of $€ 200$ million from EU grants thanks to this agreement (European Commission, 2017c).

The main purpose of this paper is to evaluate the development of Ukraine export to member states of Visegrad group depending on the exports to other countries of V4 and the level of GDP per capita in each individual country. The basis for this research was the trend analysis of the data obtained from the State Statistics Service of Ukraine, Eurostat and United Nations Conference on Trade and Development (UNCTAD), which was then statistically verified and evaluated. The UNCTAD data were retrieved on July, 2016.

\section{Theoretical Review}

The state and challenges of foreign trade are considered in a number of publications. Main tendencies and perspectives of export and import activities of Ukraine are outlined, for instance, in Deineko et al. (2015), Didkovskaya (2013), Kukharska (2016), Lomeiko (2015), Mudrak (2014), and Syvanenko and Toropkov (2015). Some authors use specific methods and 
approaches to analyze country's international trade. Bodnar (2014) elaborates econometric models which describe the state of foreign goods trade of Ukraine, in general, and with CIS, European and Asian countries separately, taking into consideration their seasonal and trend components. Also, he presents forecasted indices of Ukraine's external trade in the frame of these models.

Raneta et al. (2015) investigate Ukrainian export by means of gravity equation to identify impact of economic diplomacy and other factors on export flows. A positive relationship between Ukrainian export and the number of employees of diplomatic missions and of regional trade agreements is identified. Shumska (2014) researches the exchange rate elasticity of merchandise exports and imports of Ukraine. She evaluates the sensitivity volume of foreign trade flows of change rate in econometric models (one-factor and multi-linear regression equations) with the usage of partial indices of real effective exchange rate.

There is the lack of publications regarding export activities between Ukraine and V4 countries. With respect to foreign trade of Visegrad countries, several publications could be mentioned. Bielik et al. (2013) consider changes in agrarian trade of the Czech Republic and Slovakia in 1994-2010, characterizing comparative advantage of agricultural exports. The modified Balassa's RCA indexes and the Lafay index are applied in this article. Łapińska (2014) examines peculiarities of intra-industry trade between Poland and its EU trading partners. To measure the intensity of this trade, the Grubel-Lloyd index is employed. An econometric model is used for the analysis of the factors determining agricultural and food trade of Poland with other EU countries.

Misztal (2013) analyzes international trade and business cycle synchronization in Poland and the European Union. The researcher considers the intensity and structure of international trade and their impact on business cycle, presenting a review of the literature on macroeconomics and international finance, as well as econometric models (such as the vector autoregression model).

Multi-regression models (including in combination with other statistical methods) are also widely used in other economic studies. For instance, Aabo et al. (2016) apply multiple regression analysis to identify the impact of multinationality on the value-relevance of firms' real options. Based on this approach, they show that the relationship between stock returns and changes in return volatility is substantially connected with firm's foreign involvement. Aulová and Hlavsa (2013) study the capital structure of agricultural businesses and the effect of selected determinants on this structure. The analysis of these determinants is carried out by way of multiple linear regression. Rovný (2016) examines the position of young farmers and appropriate demographic and economic changes in the agricultural sector of the European Union. Employing the multiple regression approach, he finds out the differences and relationships between the groups of farmers under the age of 35 and above the age of 55. Ubrežiová et al. (2011) explore the position of agri-food companies and most exported agri-food commodities in SR in the European competitive environment.

Bates and Santerre (2015) analyze the demand for municipal infrastructure projects and factors which influence the capital decisionmaking process at the local government level. The researchers use the multi-regression method to have a detailed understanding of the capital-investment decision of local communities. Blyth and Kaka (2006) create a multiple linear regression model to forecast the program of works of construction companies and to produce S-curves. Received results confirm the effectiveness of the proposed model.

Bohnert et al. (2016) explore claims inflation with focus on automobile liability insurance. The drivers of claims inflation risk and its impact on reserving are determined on the ground of stepwise multiple regression analysis. Kubicová and Kádeková (2012) analyze revenue impact on the demand of Slovak households for food products. Berezan et al. (2013) examine the influence of sustainable hotel practices on the satisfaction and intention to return of hotel guests from different nationalities. Based on multiple regression and multinomial logistic regression, it is confirmed the existence of a positive relationship of these practices on guests' satisfaction levels and return intentions. Cirer Costa (2013) identifies main factors impacting price formation and market segmentation in seaside accommodations. The researcher considers tangible characteristics of each establishment, which are used as 
explanatory variables of price, on the basis of a multiple regression model.

Domingues et al. (2016) elaborate the Integrated Management Systems Maturity Model, which gives a possibility to compare integrated management systems concerning their relative stage of evolution. The researchers investigate the statistical-based component of the model, paying attention to the relationships between three independent variables and multiregression model and other variables. Døving and Martín-Rubio (2013) study the impact of team management on team-learning activities. On the basis of multi-regression analysis, they discovered that the leadership behavior of the team leader is important in terms of facilitation of team learning.

Applying multiple linear regression and binary logistic regression, Pollack and Adler (2016) find out that project management and IT skills have a significant positive influence on profitability and total sales of small to medium enterprises. Spillecke and Brettel (2013) use the multi-regression approach to determine the impact of sales management controls on the entrepreneurial orientation of the sales department (SEO). The results show that SEO is an important lever to increase performance. Pickernell et al. (2016) identify determinants of exporting activities of SME. Based on a binary logistic multiple regression approach, they discovered that SME export operations are substantially influenced by the industry sector, age and the characteristics of the SME ownermanager and the firms' available resources. Sluisa and De Giovanni (2016) research the effect of the identified key drivers for firms (supply chain coordination contracts, performance, supply chain orientation, and supply chain integration) on their likelihood of adopting a supply chain coordination contract. Multiple and multinomial logistic regressions are applied to estimate the relationships between these variables. Serwa (2013) considers the specific features of the market in terms of lending to households. The researcher employs the multi-regime regression model related to different economic states of the credit market (i.e. a normal regime or a boom regime) to identify the credit market alternates between regimes.

Zhao et al. (2016) consider the use multi regression dynamic models in the financial sector and related business areas, aimed at the improvement of forecasting and decision analysis. The research results confirm that such goal is achievable, and these models are flexible and efficient, having a variety of practical utility functions.

\section{International Position of Ukraine and V4 Group}

Even though Ukraine belongs to one of the largest countries situated in Europe, it is not the EU member on the contrary to the countries of V4 group. Still, Ukraine made the following agreements enabling cooperation with the V4 countries:

- with the Czech Republic: Treaty on Friendly Relations and Cooperation between Ukraine and the Czech Republic, Agreement between the Government of Ukraine and the Government of the Czech Republic on Economic, Industrial, Scientific and Technical Cooperation;

- with Hungary: Treaty on Basics of Good Neighborship and Cooperation between Ukraine and the Republic of Hungary, Agreement between the Government of Ukraine and the Government of the Republic of Hungary on Economic Cooperation;

- with Poland: Treaty between Ukraine and the Republic of Poland on Good Neighborship, Friendly Relations and Cooperation, Agreement between the Government of Ukraine and the Government of the Republic of Poland on Economic Cooperation;

- with the Slovak Republic: Treaty on Good Neighborship, Friendly Relations and Cooperation between Ukraine and the Slovak Republic, Agreement between the Government of Ukraine and the Government of the Slovak Republic on Economic, Industrial and Scientific and Technical Cooperation.

The present V4 group has declared a few common targets since its foundation in 1991, on which their cooperation within as well as outside the group is based. The targets are as follows: development of democracy and state sovereignty, protection of human rights, working on a modern market economy, taking part in European economic, political, security and legal systems. (Visegradgroup, 1991). All V4 countries have found various ways of cooperation in social as well as business areas with Ukraine. 
The openness of Ukraine to foreign trade is depicted by the data of State Statistics Service of Ukraine. A driving force of Ukraine and its economy are household expenses $(60 \%)$, whereas the investments form just $20 \%$. Verkhovod and Petrenko (2014) state that a reason for such low domestic incentive can be a certain amount of skepticism regarding creditgranting or human capital underfinancing, which is the source of innovative potential. A decrease in revenues caused by this can be regarded as a barrier on the economic growth. It is an unbalanced distribution of investment incentives that prevent Ukraine companies from having innovative potential and therefore, causing a decline in their revenues.

According to the data from the State Statistics Service of Ukraine (2017), the export share on GDP oscillates between $45-48 \%$, whereas the import values slightly exceed and form approximately $48-52 \%$ of GDP. FornalskaSkurczyńska (2015) stresses the supporting role of state when mentioning export. Effective forms of supporting exporting companies from government are suitable promotion programs with an emphasis on firms' productivity and export assistance. The European Commission (2017b) has shown a database about development of international trade between EU and Ukraine. Among the main export trade flows from Ukraine are as follows: base metals and articles thereof; vegetable products; mineral products; machinery and appliances; animal or vegetable fats and oils; foodstuffs; beverages; tobacco; products of the chemical or allied industries. On the contrary, the following products are mostly imported: mineral products; machinery and appliances; products of the chemical or allied industries; plastics, rubber and articles thereof. The highest share in export $(34 \%)$ as well as in import $(40 \%)$ represents the importance of a territorial link between Ukraine and EU as a whole. The second most important link of Ukraine concerning international trade is the area of Russian Federation. (BusinessInfo.cz, 2016) Doing business within EU has been made possible since $1^{\text {st }}$ June 2016 by DCFTA, which is a part of Association Agreement (AA). The Eurostat indicators (2017) highlight a small share of import $(0.4 \%)$ as well as the export of Ukraine to Eurozone countries (where only Slovakia is the member from the V4).

\section{Fig. 1: Main trade partners of V4 countries}

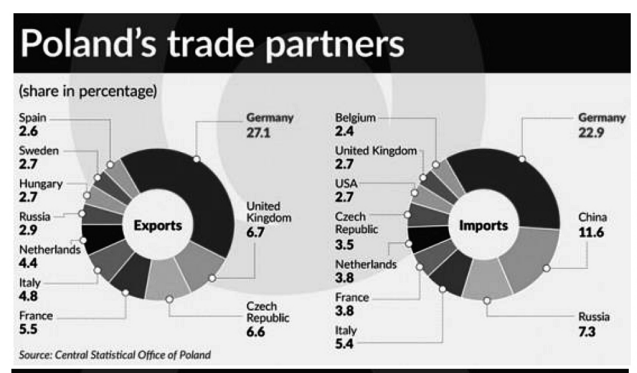

\section{Trade partners of the Czech Republic}
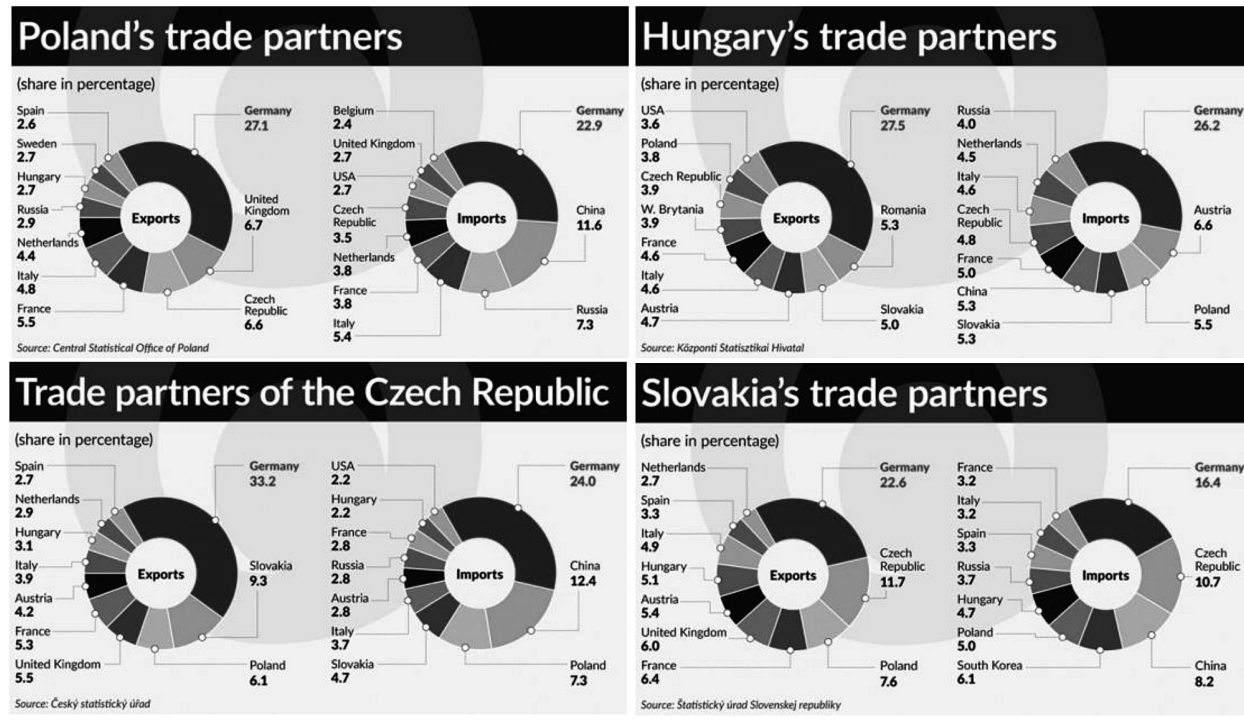

\section{Slovakia's trade partners}

(share in percentage)

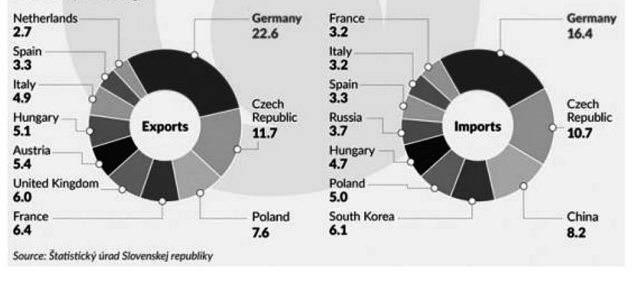

Source: Witold Gadomski (2016-10-28). The Visegrad Group countries are closer politically than economically. Retrieved from http://www.financialobserver.eu/poland/the-visegrad-group-countries-are-closer-politically-than-economically/. 
Although it seems to be an insignificant share from Eurozone's perspective, for example, Germany represents a very important business partner for Ukraine. The V4 countries are other important European partners, and these are in the following order - Poland, Hungary, Czech Republic and Slovakia. (European Commission, 2017c; BusinessInfo.cz, 2016)

Gadomski (2016) analyzed main export and import partners of Visegrad countries for the year 2015 (see Fig. 1). All the countries are primarily dependent on German exports and imports. Moreover, there is the fact of dependency of the countries among each other. For these countries, doing business with Ukraine forms less than $3 \%$ out of their total foreign trade.

\section{Data and Methodology}

The input data for the analysis were explicitly obtained from the State Statistics Service of Ukraine. These were from the years 2002-2013 inclusive. Among the main testing variables, the following ones were chosen:

- the export from Ukraine, the Czech Republic, Hungary, Poland and Slovakia among each other;

- the GDP per capita in Ukraine, the Czech Republic, Hungary, Poland and Slovakia.

Nominated variables were selected because both GDP and export are closely related and the authors were interested in the extent to which these variables affect export to V4 countries. The data obtained from the time line were then used for the purpose of a more detailed trend analysis using the statistical software Gretl.

To understand the mechanism and causes for the development trends in examined economic, social or biological processes assumes the need to handle some procedures that allow to describe the development characteristics of some indicators and thus to understand the mechanisms determining this development.

The simplest concept for modeling real values time series $y_{t}$ is one-dimensional model in the shape of the one of elementary functions:

$$
Y_{t}^{\prime}=f(t)
$$

where $Y^{\prime}$ is expected value of the indicator at time $\boldsymbol{t}$. And such that the difference as follows:

$$
y_{t}-Y_{t}^{\prime}=\varepsilon_{t},
$$

called irregular components (random errors), were altogether minimal and included the influence of other factors besides time.

The trend component reflects long-term changes in the average behavior of the time series (e.g. long-term growth and long-term decline). It arises from the action of forces that systematically act in the same direction.

One of the most important tasks of the time series analysis is to capture in an appropriate form the overall general trend in the evolution of observed indicator (Obtulovič, 2010).

In trend analysis for the period of 2002 to 2013, we used the log-log linear model displayed below in its general form:

$$
\begin{aligned}
& \log s=b_{0}+b_{1} \log x_{1}+b_{2} \log x_{2}+ \\
& +b_{3} \log x_{3}+b_{4} \log x_{4}+b_{5} \log x_{5}+ \\
& +b_{6} \log x_{6}+b_{7} \log x_{7}+b_{8} \log x_{8} .
\end{aligned}
$$

Using this model, we investigated the amount of export from Ukraine to the V4 countries (the dependent variable) while changing the independent variables (volume of export to V4 and GDP per capita in Ukraine and V4 countries).

Processing had been performed with GRETL software application. Another method we used is multi-factorial analysis of variance, based on which we investigated the significance of differences in export of agricultural commodity sections (live animals and animal products, animal and vegetable fats and oils and plant products) between the V4 countries and volumes of export between the sections. Software application Statgraphics had been used for the processing.

Based on the values measured through multi-factor analysis of variance we can examine whether the factor averages differ at the individual levels, which is possible to formulate into a symbolic inscription as a null hypothesis $\left(\mathrm{H}_{0}\right)$ in the form:

$$
H_{0}: \mu_{1}=\mu_{2}=\Lambda=\mu_{m}
$$

In null hypothesis we state that the average values of individual factor levels do not significantly differ. An alternative hypothesis contradicts the null hypothesis, i.e. at least one median value $\mu_{i}$ is significantly different from the others. Test criterion is based on 
the decomposition of total variability to the variability between the classes and within the classes.

In case we reject the null hypothesis and accept the alternative one, we also have to find out which factor levels are statistically significantly different, and which we consider to be nearly identical. Analysis of variance is then supplemented by further evaluation, called contrast analysis. In this article, we used the least significant difference test - LSD test. Obtulovič (2010) defined that by below relationship:

$$
\left|y_{i \bullet}-y_{j \bullet}\right| \geq t_{n-m}\left(\frac{\alpha}{2}\right) \cdot s \cdot \sqrt{\left(\frac{1}{r_{i}}+\frac{1}{r_{j}}\right)}
$$

\section{Results}

In this part of the project we dealt with the analysis of the export of products from Ukraine to the V4 countries (Czech Republic, Hungary, Poland, and Slovak Republic). In ascertaining the dependence of export of goods from
Ukraine we used a log-log linear multiple model where the dependent variable is always export to the individual V4 country and independent variables were the amounts of export to the other V4 countries (in thousands USD) and their GDP per capita (in thousands USD).

\subsection{Export of Goods from Ukraine to the Czech Republic}

In the case of export from Ukraine to the Czech Republic is the particular shape of the model as follows: $\operatorname{logs}=-0.71 \log x_{1}+1.6 \log x_{2}-3.77 \log x_{5}$ (P-value: $0.034,0.023,0.018)$. Development of the export from Ukraine to Czech Republic for the period 2002-2013 is presented in Fig. 2. This figure shows a growing trend of exports from Ukraine to the Czech Republic already in 2002. A sharp decline in exports is displayed for the year 2009. This decline reflects the impact of the economic crisis and a decline in GDP in the Czech Republic. The exports to the Czech Republic have continued with a slightly increasing trend since 2010. Its statistical analysis is presented in Tab. 1.

\section{Fig. 2: Development of export from Ukraine to the Czech Republic}

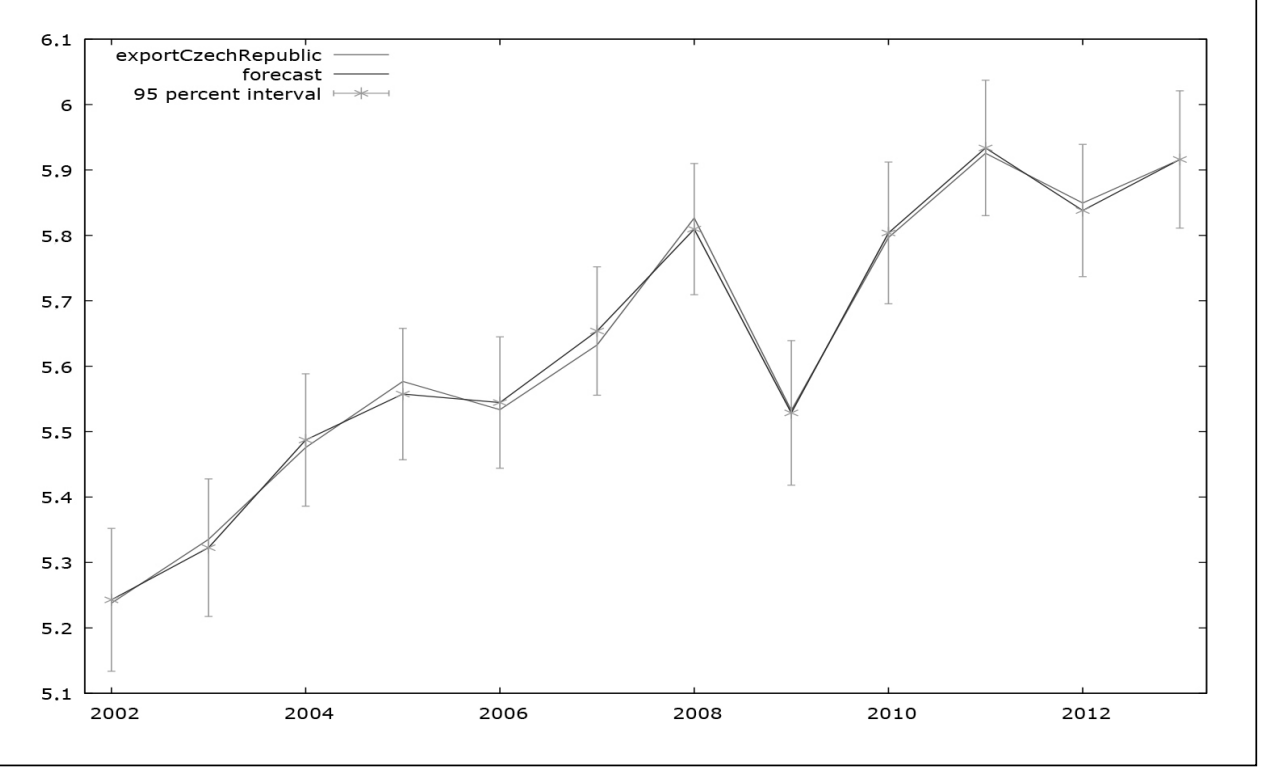

Source: own processing by the software GRETL based on the data of State Statistics Service of Ukraine (http://www.ukrstat.gov.ua/operativ/operativ2016/zd/ztt/ztt_u/ztt0816_u.htm) and UNCTAD (http://unctadstat.unctad.org/wds/TableViewer/tableView.aspx?Reportld=96) 
Model 1: OLS, using observations 2002-2013 ( $T=12)$

Dependent variable: export Czech Republic

\begin{tabular}{l|c|c|c|c}
\hline & coefficient & std. ratio & t-ratio & p-value \\
\hline const & 0.858 & 1.514 & 0.567 & 0.610 \\
\hline export Hungary & -0.715 & 0.193 & -3.700 & $0.034^{* *}$ \\
\hline export Poland & 1.614 & 0.375 & 4.307 & $0.023^{* *}$ \\
\hline export Slovakia & -0.256 & 0.569 & -0.449 & 0.684 \\
\hline GDP Ukraine per cap. & -0.694 & 0.341 & -2.033 & 0.135 \\
\hline GDP Czech Republic per cap. & -3.769 & 0.802 & -4.698 & $0.018^{* *}$ \\
\hline GDP Hungary per cap. & 2.312 & 0.976 & 2.370 & $0.099^{*}$ \\
\hline GDP Poland per cap. & 3.343 & 1.302 & 2.568 & $0.083^{*}$ \\
\hline GDP Slovakia per cap. & -0.379 & 1.179 & -0.321 & 0.769 \\
\hline Mean dependent var & 5.637 & S.D. dependent var & 0.227 \\
\hline Sum squared resid & 0.0018 & S.E. of regression & 0.025 \\
\hline R-squared & 0.9968 & Adjusted R-squared & 0.988 \\
\hline F(8, 3) & 116.980 & P-value (F) & 0.0012 \\
\hline Log-likelihood & 35.739 & Akaike criterion & -53.478 \\
\hline Schwarz criterion & -49.114 & Hannan-Quinn & -55.094 \\
\hline rho & -0.426 & Durbin-Watson & 2.838 \\
\hline
\end{tabular}

Source: own processing by the software GRETL based on the data of State Statistics Service of Ukraine (http://www.ukrstat.gov.ua/operativ/operativ2016/zd/ztt/ztt_u/ztt0816_u.htm) and UNCTAD (http://unctadstat.unctad.org/wds/TableViewer/tableView.aspx?Reportld=96)

This model was statistically significant $\left(R^{2}=0.997\right)$. The statistical significance of the p-value (table sign ${ }^{* *}$ ) was recorded for the following three independent variables: export to Hungary; export to Poland and GDP Czech Republic per capita. The result data show an increase in export to the Czech Republic with a positive line with export to Poland. The increase of $1 \%$ of export to Poland caused an increase of $1.61 \%$. There was a negative connection with export to Hungary where an increase of $1 \%$ export to Hungary meant a decrease of export to the Czech Republic of $0.71 \%$. Last significant result was indicated as decrease of $3.77 \%$ in export to the Czech Republic with an increase of $1 \%$ of GDP per capita in the Czech Republic.

\subsection{Export of Goods from Ukraine to Hungary}

Development of the export from Ukraine to Hungary for the period $2002-2013$ is shown in Fig. 3. This graph shows a growing trend of exports to Hungary over the reporting period. A slight decrease was recorded in 2005 and a significant decrease in 2009 as in the case of exports to the Czech Republic. In the case of export from Ukraine to Hungary, the particular model form is as follows:

$\operatorname{logs}=-1.15 \log x_{1}+2.11 \log x_{2}-4.49 \log x_{5}$ (Statistically significant for three independent variables: $x_{1}=$ export to the Czech Republic, $\mathrm{x}_{2}=$ export to Poland and $\mathrm{x}_{5}=\mathrm{GDP} /$ capita in Czech Republic, P-value: 0.034, 0.01, 0.048).

The results show that $1 \%$ increase in export to the Czech Republic causes a decrease in export to Hungary by an average of $1.15 \%$. On the contrary, $1 \%$ increase in export to Poland shows an average increase of export to Hungary by $2.11 \%$. The increase in GDP per capita in the Czech Republic by $1 \%$ causes a decrease in export to Hungary by an average of $4.49 \%$. The values of two independent variables: export to Poland and GDP Czech Republic 


\section{Fig. 3: Development of export from Ukraine to Hungary}

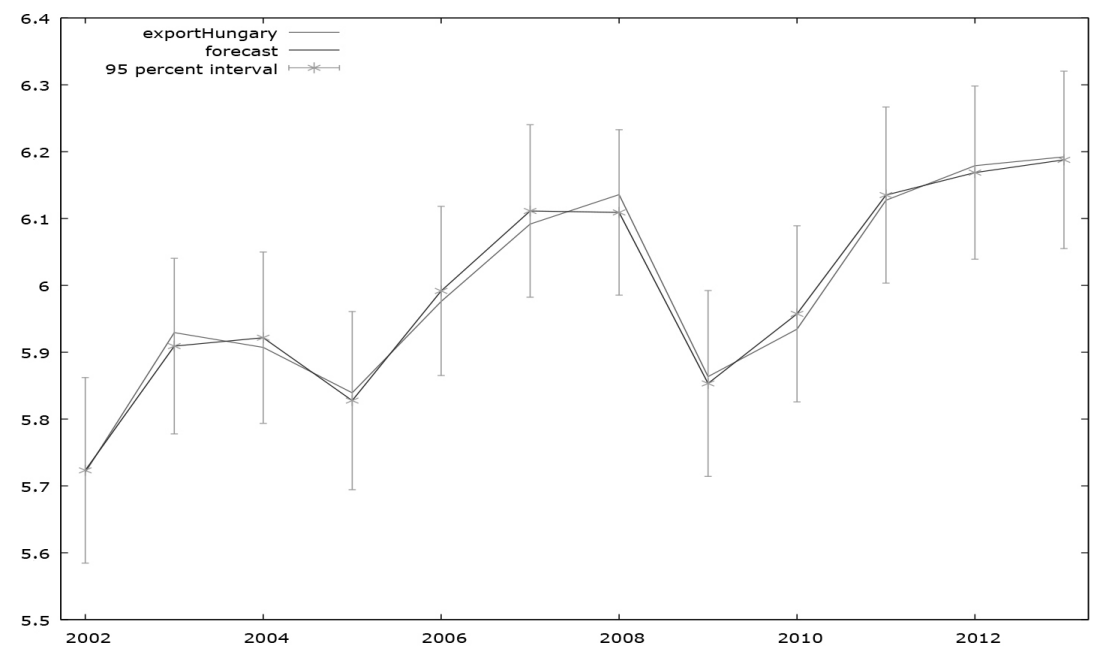

Source: own processing by the software GRETL based on the data of State Statistics Service of Ukraine (http://www.ukrstat.gov.ua/operativ/operativ2016/zd/ztt/ztt_u/ztt0816_u.htm) and UNCTAD (http://unctadstat.unctad.org/wds/TableViewer/tableView.aspx?Reportld=96)

per capita are copying the positive/negative development of previous results of exports to the Czech Republic. This model was statistically significant $\left(R^{2}=0.988\right)$. The statistical analysis of development of export to Hungary is presented in Tab. 2.

\subsection{Export of Goods from Ukraine to Poland}

Development of the export from Ukraine to Poland for the period 2002-2013 is presented in the following Fig. 4. The economic crisis of 2009 again interrupted a growing trend of exports to Poland. A very similar graph was illustrated in Fig. 2 for exports to the Czech Republic. When analyzing export from Ukraine to Poland, the particular shape of the model is as follows:

$\operatorname{logs}=0.53 \log x_{1}+0.43 \log x_{2}+2.03 \log x_{5}-$ $-1.5 \log x_{6}-2.09 \log x_{7}$ (Statistically significant for five independent variables, where $x_{1}=$ export to the Czech Republic, $x_{2}=$ export to Hungary, $\mathrm{x}_{5}=\mathrm{GDP} /$ capita in the Czech Republic, $\mathrm{x}_{6}=\mathrm{GDP} /$ capita in Hungary, $\mathrm{x}_{7}=\mathrm{GDP} /$ capita in Poland, P-value: 0.023, 0.01, 0.049, 0.031, 0.037).
The results show that $1 \%$ increase in export to the Czech Republic produces an increase in export to Poland by an average of $0.53 \% .1 \%$ increase in export to Hungary would increase on average the export to Poland by $0.43 \%$. Increase in GDP/capita in the Czech Republic by $1 \%$ causes an increase in export to Poland on average by $2.03 \%$ while increase in GDP/ capita in Hungary would cause a reduction in export to Poland by an average of $1.5 \%$. An increase in GDP/capita in Poland would cause a reduction in export to Poland by an average of $2.09 \%$. This model is statistically significant $\left(R^{2}=0.999\right)$. Statistical analysis of development of export to Poland could be seen in Tab. 3 .

\subsection{Export of Goods from Ukraine to the Slovak Republic}

Development of the export from Ukraine to the Slovak Republic for the period 2002-2013 is presented in Fig. 5. The development trend corresponds to previous developments in Fig. 2 (Export to the Czech Republic) and Fig. 4 (Export to Poland). An enormous decline in exports to the Slovak Republic was displayed 


\section{Tab. 2: Statistical analysis of export development from Ukraine to Hungary}

\begin{tabular}{|c|c|c|c|c|}
\hline \multicolumn{5}{|c|}{ Dependent variable: export Hungary } \\
\hline & coefficient & std. ratio & t-ratio & p-value \\
\hline const & 1.838 & 1.718 & 1.070 & 0.363 \\
\hline export Czech Republic & -1.148 & 0.310 & -3.700 & 0.034 ** \\
\hline export Poland & 2.112 & 0.366 & 5.766 & 0.010 ** \\
\hline export Slovakia & -0.552 & 0.673 & -0.820 & 0.473 \\
\hline GDP Ukraine per cap. & -0.673 & 0.542 & -1.241 & 0.303 \\
\hline GDP Czech Republic per cap. & -4.490 & 1.386 & -3.239 & $0.048^{* *}$ \\
\hline GDP Hungary per cap. & 3.067 & 1.120 & 2.738 & 0.071 * \\
\hline GDP Poland per cap. & 4.147 & 1.724 & 2.406 & 0.095 * \\
\hline GDP Slovakia per cap. & -0.890 & 1.431 & -0.622 & 0.578 \\
\hline Mean dependent var & 5.991 & \multicolumn{2}{|c|}{ S.D. dependent var } & 0.151 \\
\hline Sum squared resid & 0.003 & \multicolumn{2}{|c|}{ S.E. of regression } & 0.031 \\
\hline R-squared & 0.988 & \multicolumn{2}{|c|}{ Adjusted R-squared } & 0.958 \\
\hline$F(8,3)$ & 32.021 & \multicolumn{2}{|l|}{ P-value (F) } & 0.008 \\
\hline Log-likelihood & 32.896 & \multicolumn{2}{|c|}{ Akaike criterion } & -47.793 \\
\hline Schwarz criterion & -43.429 & \multicolumn{2}{|c|}{ Hannan-Quinn } & -49.409 \\
\hline rho & -0.254 & \multicolumn{2}{|c|}{ Durbin-Watson } & 2.495 \\
\hline
\end{tabular}

Source: own processing by the software GRETL based on the data of State Statistics Service of Ukraine (http://www.ukrstat.gov.ua/operativ/operativ2016/zd/ztt/ztt_u/ztt0816_u.htm) and UNCTAD (http://unctadstat.unctad.org/wds/TableViewer/tableView.aspx?Reportld=96)

for the 2009. The particular shape of the model in the analysis of export from Ukraine to Slovakia is as follows: $\operatorname{logs}=-1.94 \log x_{8}$ (Statistically significant for one independent variable only, where $\mathrm{x}_{8}=\mathrm{GDP} /$ capita in Slovakia, P-value: 0.014).

The results indicate an increase in GDP per capita in Slovakia would cause a decrease in export to Slovakia by an average of $1.94 \%$. The model is statistically significant $\left(R^{2}=0.994\right)$. Statistical analysis of development of export to Slovakia is given in Tab. 4.

Comprehensive look at the export shows the following results. Increase in export of products to the Czech Republic is positively tied to the increase in export to Poland, negatively tied with an increase of GDP per capita in the Czech Republic and the increased export to Hungary. Increase in export of goods to Hungary is positively linked with an increase in export to Poland, negatively with an increase in export to the Czech Republic and with increase in GDP per capita in the Czech Republic. Increased export to Poland is positively linked with an increase in export to the Czech Republic, the increase in export to Hungary, with an increase in GDP per capita in the Czech Republic and negatively tied with an increase in GDP per capita in Hungary and Poland. Growth of export to Slovakia is negatively linked only with an increase in GDP per capita in Slovakia. In our opinion, the existence of a negative relationship between the volume of Ukrainian export and GDP per capita in Visegrad countries can be explained that, in case of the improvement of economic situation in the V4 countries and the increase of income of their population, a large number of customers change their preferences and buy more expensive goods manufactured outside of Ukraine. Generalization of the results of the regression analysis is presented in Tab. 5 . 


\section{Fig. 4: Development of export from Ukraine to Poland}

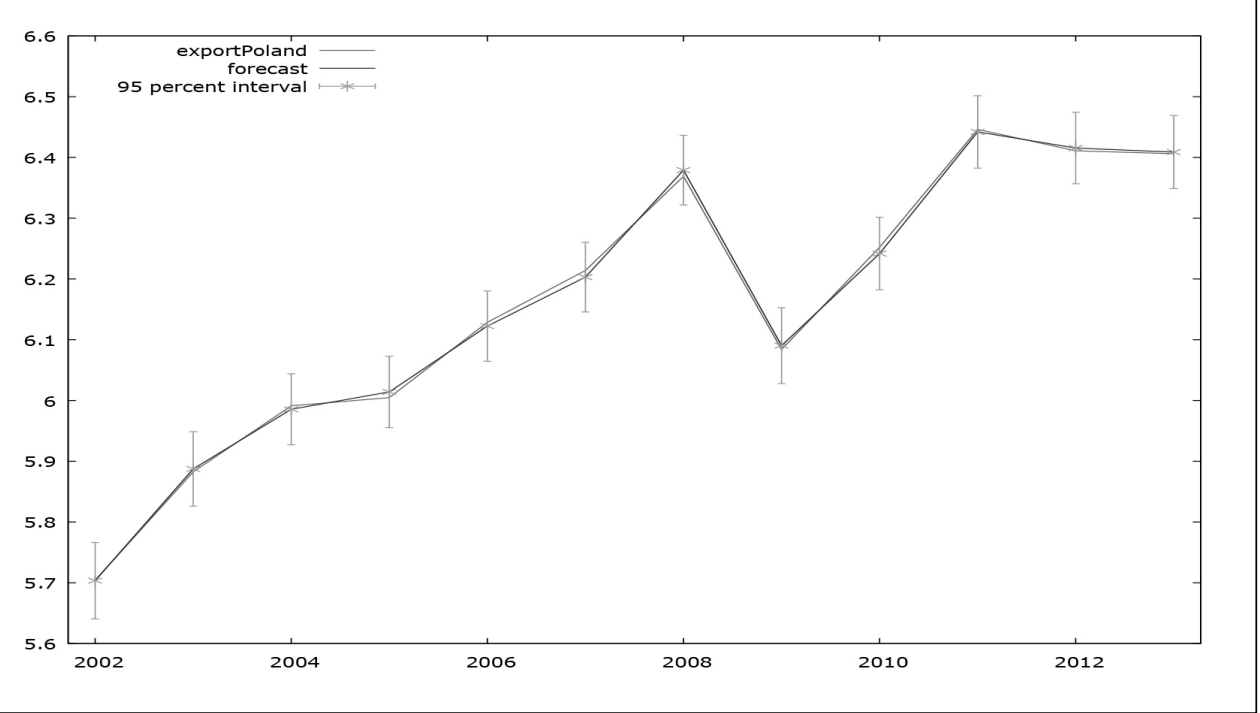

Source: own processing by the software GRETL based on the data of State Statistics Service of Ukraine (http://www.ukrstat.gov.ua/operativ/operativ2016/zd/ztt/ztt_u/ztt0816_u.htm) and UNCTAD (http://unctadstat.unctad.org/wds/TableViewer/tableView.aspx?Reportld=96)

\section{Fig. 5: Development of export from Ukraine to the Slovak Republic}

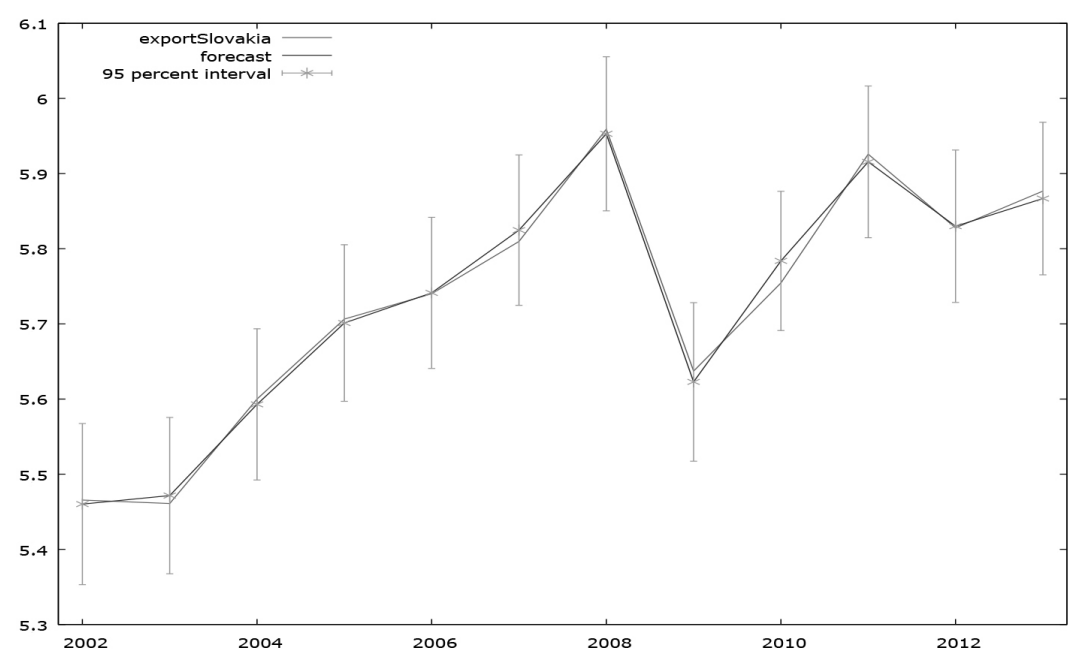

Source: own processing by the software GRETL based on the data of State Statistics Service of Ukraine (http://www.ukrstat.gov.ua/operativ/operativ2016/zd/ztt/ztt_u/ztt0816_u.htm) and UNCTAD (http://unctadstat.unctad.org/wds/TableViewer/tableView.aspx?Reportld=96) 
Tab. 3: Statistical analysis of export development from Ukraine to Poland

\begin{tabular}{|c|c|c|c|c|}
\hline \multicolumn{5}{|c|}{ Dependent variable: export Poland } \\
\hline & coefficient & std. ratio & t-ratio & p-value \\
\hline const & -0.785 & 0.796 & -0.987 & 0.396 \\
\hline export Czech Republic & 0.533 & 0.124 & 4.307 & $0.023 * *$ \\
\hline export Hungary & 0.434 & 0.075 & 5.766 & 0.010 ** \\
\hline export Slovakia & 0.319 & 0.283 & 1.127 & 0.342 \\
\hline GDP Ukraine per cap. & 0.353 & 0.224 & 1.578 & 0.213 \\
\hline GDP Czech Republic per cap. & 2.031 & 0.634 & 3.206 & 0.049 ** \\
\hline GDP Hungary per cap. & -1.502 & 0.389 & -3.865 & $0.031^{* *}$ \\
\hline GDP Poland per cap. & -2.089 & 0.580 & -3.605 & $0.037^{* *}$ \\
\hline GDP Slovakia per cap. & 0.563 & 0.608 & 0.927 & 0.422 \\
\hline Mean dependent var & 6.158 & \multicolumn{2}{|c|}{ S.D. dependent var } & 0.234 \\
\hline Sum squared resid & 0.0006 & \multicolumn{2}{|c|}{ S.E. of regression } & 0.014 \\
\hline R-squared & 0.999 & \multicolumn{2}{|c|}{ Adjusted R-squared } & 0.996 \\
\hline$F(8,3)$ & 377.008 & \multicolumn{2}{|c|}{$P$-value $(F)$} & 0.0002 \\
\hline Log-likelihood & 42.385 & \multicolumn{2}{|c|}{ Akaike criterion } & -66.771 \\
\hline Schwarz criterion & -62.407 & \multicolumn{2}{|c|}{ Hannan-Quinn } & -68.387 \\
\hline rho & -0.254 & \multicolumn{2}{|c|}{ Durbin-Watson } & 2.491 \\
\hline
\end{tabular}

Source: own processing by the software GRETL based on the data of State Statistics Service of Ukraine (http://www.ukrstat.gov.ua/operativ/operativ2016/zd/ztt/ztt_u/ztt0816_u.htm) and UNCTAD (http://unctadstat.unctad.org/wds/TableViewer/tableView.aspx?Reportld=96)

The database from the European Commission (2017b) revealed a clear structure of international trade of Ukraine. Among the main export items of Ukraine to the EU, there are also agricultural and food commodities such as vegetable products, animal products of vegetable fats and oils. There are few studies, as of the authors (Bielik et al., 2013), Łapińska (2014), Rovný (2016), Ubrežiová et al. (2011), which have paid attention to the agricultural area in connection with foreign trade in some of the EU member countries.

The next part of this paper is dealing with analysis of trade by agri-food commodity groups, such as live animals and animal products, animal and vegetable fats and oils and plant products. The authors examined whether there are significant differences in export of these products between the V4 countries and at the same time whether there are also significant differences between the commodity sections and also between the surveyed years (in thousands of USD). The method used is multifactorial analysis of variance. Processing had been implemented in statistical software Statgraphics. From the analysis (Tab. 6), the authors deduced that the reference years do not affect the export from Ukraine. The hypothesis $\mathrm{H}_{0}$, which indicates no dependence of agri-food commodity with the period surveyed, could not been rejected. The export amount is about the same level each year $(P$-value $=0.79$, Tab. 6$)$. However there are significant differences between the countries $(P$-value $=0.000$, Tab. 6$)$, where Poland significantly differs from the other V4 countries, with USD 89,627.9 thousand the average value of export from Ukraine (Tab. 7). There are significant differences between categories as well $(P$-value $=0.0002$, Tab. 6$)$, where the amount of plant products export is considerably different from the rest, with an average value of USD 55,907.2 thousand (Tab. 8). 


\section{Tab. 4: Statistical analysis of export development from Ukraine to the Slovak Republic}

Model 4: OLS, using observations 2002-2013 ( $\mathrm{T}=12$ )

\section{Dependent variable: export Slovakia}

\begin{tabular}{l|c|c|c|c}
\hline & coefficient & std. ratio & t-ratio & p-value \\
\hline const & 2.131 & 0.968 & 2.202 & 0.115 \\
\hline export Czech Republic & -0.247 & 0.549 & -0.450 & 0.684 \\
\hline export Hungary & -0.331 & 0.404 & -0.820 & 0.473 \\
\hline export Poland & 0.932 & 0.827 & 1.127 & 0.342 \\
\hline GDP Ukraine per cap. & -0.083 & 0.515 & -0.161 & 0.882 \\
\hline GDP Czech Republic per cap. & -1.060 & 2.194 & -0.483 & 0.662 \\
\hline GDP Hungary per cap. & 1.958 & 1.166 & 1.679 & 0.192 \\
\hline GDP Poland per cap. & 2.561 & 1.744 & 1.468 & 0.238 \\
\hline GDP Slovakia per cap. & -1.937 & 0.371 & -5.217 & 0.014 ** \\
\hline Mean dependent var & 5.730 & S.D. dependent var & 0.164 \\
\hline Sum squared resid & 0.002 & S.E. of regression & 0.024 \\
\hline R-squared & 0.994 & Adjusted R-squared & 0.978 \\
\hline F(8, 3) & 63.168 & P-value (F) & 0.003 \\
\hline Log-likelihood & 35.955 & Akaike criterion & -53.910 \\
\hline Schwarz criterion & -49.546 & Hannan-Quinn & -55.526 \\
\hline rho & -0.513 & Durbin-Watson & 2.896 \\
\hline
\end{tabular}

Source: own processing by the software GRETL based on the data of State Statistics Service of Ukraine (http://www.ukrstat.gov.ua/operativ/operativ2016/zd/ztt/ztt_u/ztt0816_u.htm) and UNCTAD

(http://unctadstat.unctad.org/wds/TableViewer/tableView.aspx?Reportld=96)

\begin{tabular}{|c|c|c|c|c|c|c|c|c|}
\hline $\begin{array}{l}\text { Depen } \\
\text { factors }\end{array}$ & ence of & xport of & oduct & rom Uk & ine to $\mathrm{V}$ & countri & on se & cted \\
\hline \multirow{2}{*}{$\begin{array}{l}\text { Export of products } \\
\text { from Ukraine }\end{array}$} & \multicolumn{4}{|c|}{ Export of products from Ukraine } & \multicolumn{4}{|c|}{ GDP per capita } \\
\hline & $\begin{array}{l}\text { Czech } \\
\text { Republic }\end{array}$ & Hungary & Poland & $\begin{array}{l}\text { Slovak } \\
\text { Republic }\end{array}$ & $\begin{array}{l}\text { Czech } \\
\text { Republic }\end{array}$ & Hungary & Poland & $\begin{array}{c}\text { Slovak } \\
\text { Republic }\end{array}$ \\
\hline Czech Republic & $x$ & - & + & & - & & & \\
\hline Hungary & - & $x$ & + & & - & & & \\
\hline Poland & + & + & $x$ & & + & - & - & \\
\hline Slovak Republic & & & & $x$ & & & & - \\
\hline
\end{tabular}

Source: own composition based on previous calculations in this paper

\section{Discussion}

The final evaluations of Ukraine export to Visegrad countries between 2002-2013 demonstrated dependencies on independent variables of export to other V4 countries and the level of GDP per capita. According to number of statistically significant dependencies, the following order was stated (starting from the highest degree of dependency): Poland, Hungary and the Czech Republic, Slovakia. This fact also corresponds with the macroeconomic data of Ukraine export to V4 countries. (BusinessInfo.cz, 2016; European Commission, 2017b; Eurostat, 2017c; Gadomski, 2016; State Statistics Service of Ukraine, 2017). Misztal (2013) pointed out the 
Tab. 6: Analysis of variance for thousands of USD - Type III sums of squares

\begin{tabular}{l|c|c|c|c|c}
\multicolumn{1}{c|}{ Main Effects/Source } & Sum of Squares & Df & Mean Square & F-Ratio & P-Value \\
\hline A: country & $7.7648 \mathrm{E} 10$ & 3 & $2.58827 \mathrm{E} 10$ & 18.54 & 0.0000 \\
\hline B: category & $2.82399 \mathrm{E} 10$ & 2 & $1.41199 \mathrm{E} 10$ & 10.12 & 0.0002 \\
\hline C: years & $2.38284 \mathrm{E} 9$ & 4 & $5.9571 \mathrm{E} 8$ & 0.43 & 0.7886 \\
\hline RESIDUAL & $6.97874 \mathrm{E} 10$ & 50 & $1.39575 \mathrm{E} 9$ & & \\
\hline TOTAL (CORRECTED) & $1.78058 \mathrm{E} 11$ & 59 & & & \\
\hline
\end{tabular}

Source: own processing by the software Statgraphics based on the data of State Statistics Service of Ukraine (http://www.ukrstat.gov.ua/operativ/operativ2016/zd/kr_tstr/arh_kr_2016.htm)

Method: $95.0 \%$ scheffe

\begin{tabular}{l|c|c|c}
\multicolumn{1}{c|}{ Country } & Count & LS Mean & Homogeneous Groups \\
\hline Slovak Republic & 15 & $3,895.63$ & $\mathrm{X}$ \\
\hline Czech Republic & 15 & $4,613.38$ & $\mathrm{X}$ \\
\hline Hungary & 15 & $12,146.9$ & $\mathrm{X}$ \\
\hline Poland & 15 & $89,627.9$ & $\mathrm{X}$ \\
\hline
\end{tabular}

Source: own processing by the software Statgraphics based on the data of State Statistics Service of Ukraine (http://www.ukrstat.gov.ua/operativ/operativ2016/zd/kr_tstr/arh_kr_2016.htm)

\section{Tab. 8: Method: $95.0 \%$ scheffe}

\begin{tabular}{l|c|c|c}
\multicolumn{1}{c|}{ Commodity group } & Count & LS Mean & Homogeneous Groups \\
\hline I. Live animals and livestock products & 20 & $3,215.04$ & $\mathrm{X}$ \\
\hline III. Animal or plant fats and oils & 20 & $23,590.6$ & $\mathrm{X}$ \\
\hline II. Plant products & 20 & $55,907.2$ & $\mathrm{X}$ \\
\hline
\end{tabular}

Source: own processing by the software Statgraphics based on the data of State Statistics Service of Ukraine (http://www.ukrstat.gov.ua/operativ/operativ2016/zd/kr_tstr/arh_kr_2016.htm)

macroeconomic context of export to Poland, as one of the most significant business partners of Ukraine. The econometric model of significance of Polish trade with foodstuff was also proved in the research of Łapińska (2014). Although the highest number of dependencies was in case of Poland, the export to Hungary was confirmed to have the highest number of dependencies. On the contrary, the lowest dependency rate was recorded in Slovakia. Regarding this business partner, the level of GDP per capita is the major factor negatively influencing Ukraine export. Despite these results, as Fitzová and Žídek (2015) state, foreign trade promotes substantially economic growth of Slovakia. In case of V4 countries among each other only, there is close cooperation when mentioning foreign trade. This fact can also be revealed by studying the statistics of an export/import share to particular EU countries (Gadomski). Foreign fair trade for V4 countries is secured by the EU agreements. The EU has concluded bilateral agreements supporting international trade with some of non-member states. It is the case of Ukraine as well. In addition, based on these agreements, Ukraine has access to particular European funds (European Commission, 2017a).

The authors suggest that Ukraine's export trade is substantially oriented towards plant products because of several reasons. Firstly, there are favorable soil and climatic conditions 
which promote production of agricultural crops in the country. Secondly, capital turnover in plant-growing is faster than in livestock breeding. Thirdly, the export procedure regarding plant products is easier compared to, for example, livestock products, which also has a positive impact on the development of this type of export. This proposal has also been supported by present export portfolio recorded by the European Commission (2017b). Vegetable products and animal or vegetable fats and oils are really the main export articles of Ukraine.

The received results show that there are various interdependences between Ukraine and V4 countries on export activities and GDP. To determine appropriate reasons of these interdependences, an additional analysis will be required regarding the commodity structure of export operations and identification of trade specialization of countries, which might be conducted in further research studies.

\section{Conclusion}

The study of peculiarities of development of Ukrainian international trade is essential, because it provides an opportunity to understand the current situation and, consequently, to find appropriate possibilities to overcome existing obstacles and to improve the economic state of the country. The aim of the submitted paper was to determine the development of export of goods from Ukraine to V4 countries. From the analyzes that were performed by using the software GRETL and log-log linear model, we concluded that export to selected countries V4 is influenced on the one hand by exports to other V4 countries (whether positive or negative), on the other hand, also by the level of GDP per capita of the concerned country. In general, when the GDP per capita of the concerned country increases, the export to that country falls. The country most affected by foreign trade in the V4 group was Poland. The increase in exports of Ukraine to Poland positively affects exports to the Czech Republic and Hungary, and the increase in GDP in the Czech Republic also has an impact on the increase in imports from Ukraine. The increase in exports or GDP per capita in the Czech Republic and Hungary had a negative impact on Ukraine's exports to the V4 countries. Finally, the Slovak Republic only shows a negative impact on the increase in GDP per capita for exports from Ukraine.
It would be interesting to watch the cause of this decline, but because of the vastness of this problem, we do not mention this aspect in the paper.

Another aim of the paper was to investigate significance of the differences of the export of agricultural commodities between aim destinations. Analysis was performed by using the software Statgraphics by ANOVA method. A significant difference in export was confirmed in Poland (an average of 89,627.9 thousands USD) and other V4 countries (an average of $3,895.63$ to $12,146.9$ thousands USD). A significant difference was found in exports of vegetable products and the average $55,907.2$ thousands USD) and live animals (an average of $3,215.04$ to $23,590.6$ thousands USD). As in the previous section would be suitable to detect and analyze the reasons of the differences.

Overall, export of goods from Ukraine to the V4 countries throughout the analyzed period was rising, in recent years in Poland has decreased slightly. A significant decrease in export occurred in 2009, when fully reflected an economic crisis, which did not escape these countries. After this period, the positive turnover was observed.

In this paper, we considered only some aspects of export activities between Ukraine and Visegrad countries. The discovered interdependencies confirm that it is necessary to take into account existing economic and other features of these countries in the frame of a long-term strategy to be able to establish mutually beneficial trade relations with them. On this basis, it will be possible to increase the competitiveness of the Ukrainian economy and to promote its effective integration into the EU markets.

\section{References}

Aabo, T., Pantzalisb, C., \& Park, J. C. (2016). Multinationality as Real Option Facilitator - Illusion or Reality? Journal of Corporate Finance, 38, 1-17. https://dx.doi.org/10.1016/j. jcorpfin.2016.03.004.

Aulová, R., \& Hlavsa, T. (2013). Capital Structure of Agricultural Businesses and its Determinants. Agris on-line Papers in Economics and Informatics, 5(2), 23-36.

Bates, L. J., \& Santerre, R. E. (2015): The Demand for Municipal Infrastructure Projects: Some Evidence from Connecticut Towns and 
Cities. Public Finance Review, 43(5), 586-605. https://dx.doi.org/10.1177/1091142114527782.

Berezan, O., Raab, C., Yoo, M., \& Love, C. (2013). Sustainable Hotel Practices and Nationality: The impact on Guest Satisfaction and Guest Intention to Return. International Journal of Hospitality Management, 34(1), 227-233. https://dx.doi.org/10.1016/j. ijhm.2013.03.010.

Bielik, P., Smutka, L., Svatoš, M., \& Hupková, D. (2013). Czech and Slovak Agricultural Foreign Trade - Two Decades after the Dissolution. Agricultural Economics Czech, 59(10), 441-453.

Blyth, K., \& Kaka, A. (2006). A Novel Multiple Linear Regression Model for Forecasting S-curves, Engineering. Construction and Architectural Management, 13(1), 82-95. https:// dx.doi.org/10.1108/09699980610646511.

Bodnar, R. D. (2014). Econometric Analysis of Goods Foreign Trade Dynamics in Ukraine. Actual Problems of Economics, 153(3), 479-486.

Bohnert, A., Gatzert, N., \& Kolb, A. (2016). Assessing Inflation Risk in Non-life Insurance. Insurance: Mathematics and Economics, 66, 86-96. https://dx.doi.org/10.1016/j. insmatheco.2015.11.003.

BusinessInfo.cz. (2016, July 17). Ukrajina: Zahraniční obchod a investice. Retrieved February 11, 2017, from http://www. businessinfo.cz/cs/clanky/ukrajina-zahranicniobchod-a-investice-19094.html.

Cirer Costa, J. C. (2013). Price Formation and Market Segmentation in Seaside Accommodations. International Journal of Hospitality Management, 33(1), 446-455. https://dx.doi.org/10.1016/j.ijhm.2012.11.004.

Deineko, L. V., Shovkun, I. A., \& Kupchak, P. M. (2015). The Trade of Ukraine with Countries of the Custom Union: Modern Trends and Risks for the Domestic Industrial Production. Economy of Ukraine, 8, 74-90.

Didkovskaya, B. V. (2013). Foreign Trade of Ukraine with West-European Countries. Business Inform, 4, 62-67.

Domingues, P., Sampaio, P., \& Arezes, P. M. (2016). Integrated Management Systems Assessment:AMaturity Model Proposal. Journal of Cleaner Production, 124, 164-174. https:// dx.doi.org/10.1016/j.jclepro.2016.02.103.

Døving, E., \& Martín-Rubio, I. (2013). Managing Team Learning in a Spanish Commercial Bank. Journal of Workplace
Learning, 25(5), 281-295. https://dx.doi. org/10.1108/JWL-Sep-2011-0053.

European Commision. (2017a). About EU; EU funding. Retrieved February 18, 2017, from http://europa.eu/european-union/about-eu/ funding-grants_en.

European Commision. (2017b). European Union, Trade with Ukraine. Retrieved February 17, 2017, from http://trade.ec.europa.eu/doclib/ docs/2006/september/tradoc_113459.pdf.

European Commision. (2017c). European Union, Trade; Policy; Countries and Regions; Ukraine. Retrieved February 08, 2017, from http://ec.europa.eu/trade/policy/countries-andregions/countries/ukraine/.

Eurostat. (2017). Data; Database; International Trade in goods - detailed data. Retrieved February 18, 2017, from http://ec.europa.eu/eurostat/web/internationaltrade-in-goods/data/database.

Fitzová, H., \& Žídek, L. (2015). Impact of Trade on Economic Growth in the Czech and Slovak Republics. Economics and Sociology, 8(2), 36-50. https://dx.doi.org/10.14254/2071789X.2015/8-2/4.

Horák, A., Prýmek, M., Prokop, L., \& Mišák, S. (2015) Economic Aspects of Multi-Source Demand-Side Soncumption Optimization in the Smart Home Concept. Acta Polytechnica Hungarica, 12(7),89-108. https://dx.doi. org/10.12700/APH.12.7.2015.7.6.

Gadomski, W. (2016, October 28). The Visegrad Group countries are closer politically than economically. Central European Financial Observer. Retrieved February 20, 2017, from http://www.financialobserver.eu/poland/thevisegrad-group-countries-are-closer-politicallythan-economically/.

Kubicová, L'., \& Kádeková, Z. (2012) Revenue impact on the demand of slovak households for meat and meat products. Acta Universitatis Agriculturae et Silviculturae Mendelianae Brunensis, 60(2), 503-550. https://dx.doi.org/10.11118/actaun201260020503.

Kukharska, N. O. (2016). Free-trade Area Ukraine - EU: Prospects and Risks behind Implementation. Actual Problems of Economics, 177(3), 39-47.

Łapińska, J. (2014). Determinants of Intra-industry Trade in Agricultural and Food Products between Poland and EU Countries. Danube: Law and Economics Review, 5(3), 159-172. https://dx.doi.org/10.2478/danb2014-0009. 
Lomeiko, Y. A. (2015). Customs Regulation and Control in the Context of External Economic Relations Development in Ukraine. Actual Problems of Economics, 166(4), 75-93.

Misztal, P. (2013). International Trade and Business Cycle Synchronization in Poland, the European Union and the Euro Zone. Contemporary Economics, 7(3), 65-78. https://dx.doi.org/10.5709/ce.1897-9254.90.

Mudrak, R. P. (2014). The Export of Ukrainian Food Products: Status, Trends, Causes. Economy of Ukraine, 5, 70-79.

Obtulovič, P. (2010). Bioštatistika (4th ed.). Nitra: Slovenská pol'nohospodárska univerzita.

Pickernell, D., Jones, P., Thompson, P., \& Packham, G. (2016). Determinants of SME Exporting: Insights and Implications. International Journal of Entrepreneurship and Innovation, 17(1), 31-42. https://dx.doi. org/10.5367/ijei.2016.0208.

Pollack, J., \& Adler, D. (2016). Skills that Improve Profitability: The Relationship between Project Management, IT skills, and Small to Medium Enterprise Profitability. International Journal of Project Management, 34(5), 831-838. https://dx.doi.org/10.1016/j. ijproman.2016.03.004.

Raneta, L., Kunychka, M., \& Gress, M. (2015). Analysis of Ukrainian Exports in the Context of Commercial Diplomacy: Gravity Model. Actual Problems of Economics, 173(11), 43-55.

Rovný, P. (2016). The Analysis of Farm Population with respect to Young Farmers in the European Union. Procedia - Social and Behavioral Sciences, 220, 391-398. https://dx.doi.org/10.1016/j.sbspro.2016.05.513.

Olinski, M., Szamrowski, P., \& Luty, L. (2016). The Impact of EU Funds on the Development of a Business Model for Small and Medium-Sized Enterprises. Journal of Competitiveness, 8(3), 68-89. https://dx.doi. org/10.7441/joc.2016.03.05.

Serwa, D. (2013). Identifying Multiple Regimes in the Model of Credit to Households. International Review of Economics and Finance, 27, 198-208. https://dx.doi.org/10.1016/j. iref.2012.10.011.

Shumska, S. S. (2014). Short-term Exchange Rate Elasticity Evaluation Model for Ukraine's Merchandise Exports and Imports. Economic Annals-XXI, 5-6, 101-105.

Sluisa, S., \& De Giovanni, P. (2016). The Selection of Contracts in Supply Chains: An
Empirical Analysis. Journal of Operations Management, 41, 1-11. https://dx.doi. org/10.1016/j.jom.2015.10.002.

Spillecke, S. B., \& Brettel, M. (2013). The Impact of Sales Management Controls on the Entrepreneurial Orientation of the Sales Department. European Management Journal, 31(4), 410-422. https://dx.doi.org/10.1016/j. emj.2012.07.002.

State Statistics Service of Ukraine. (2017). Statistical information: Gross domestic product by final use categories. Retrieved February 8, 2017, from http://www.ukrstat.gov.ua/.

Syvanenko, G. P., \& Toropkov, V. M. (2015). Ukrainian Business Development in the Context of Eurointegration. Actual Problems of Economics, 173(11), 64-70.

Ubrežiová, I., Lenčéšová, L., \& Sedliaková, I. (2011). Position of agri-food companies and most exported agri-food commodities in SR in the European competitive environment. In Aktuálne trendy manažmentu $v$ konkurenčnom prostredí: Topol'čianky 21. 22. septembra 2011 : zborník z medzinárodnej konferencie (pp. 79-88). Nitra: SUA. Retrieved from http:// www.slpk.sk/eldo/2012/zborniky/020-12/ aktualne-trendy.pdf.

Verkhovod, I., \& Petrenko, V. (2014). Analysis of Dependence in Ukrainian Enterprises' Economic Indicators from Measure of Their Innovation Activism. Economics and Sociology, 7(3), 76-89. https://dx.doi. org/10.14254/2071-789X.2014/7-3/6.

Visegrad Group. (1991). Visegrad Declaration. Retrieved February 10, 2017, from http://www.visegradgroup.eu/documents/visegraddeclarations/visegrad-declaration-110412-2.

Vojtovič, S. (2016). The Impact of The Structural Funds on Competitiveness of Small and Medium-Sized Enterprises. Journal of Competitiveness, 8(4), 30-45. https://dx.doi. org/10.7441/joc.2016.04.02.

Zdražil, P., \& Applová, P. (2016). Growth Disparities among Regions of the Visegrad Group Countries: An Evidence of Their Extent and Nature. E\&M Ekonomie a Management, 19(2), 37-54. https://dx.doi.org/10.15240/ tul/001/2016-2-003.

Zhao, Z. Y., Xie, M., \& West, M. (2016). Dynamic Dependence Networks: Financial Time Series Forecasting and Portfolio Decisions. Applied Stochastic Models in Business and Industry, 32(3), 311-332. https:// dx.doi.org/10.1002/asmb.2165. 
prof. Ing. L'udmila Nagyová, Ph.D.

Slovak University of Agriculture in Nitra

Faculty of Economics and Management

Department of Marketing and Trade

Slovakia

Ludmila.Nagyova@uniag.sk

Ing. Monika Horáková, Ph.D. Tomas Bata University in Zlín

Faculty of Management and Economics

Department of Economics

Czech Republic

mhorakova@fame.utb.cz

doc. Ing. Serhiy Moroz, Ph.D.

Slovak University of Agriculture in Nitra

Faculty of Economics and Management

Department of Marketing and Trade

Slovakia

smorozmail@gmail.com prof. Dr. Ing. Elena Horská

Slovak University of Agriculture in Nitra Faculty of Economics and Management

Department of Marketing and Trade

Slovakia

elena.horska@uniag.sk

doc. Ing. Zuzana Poláková, Ph.D. Slovak University of Agriculture in Nitra Faculty of Economics and Management Department of Statistics and Operations Research

Slovakia zuzana.polakova@uniag.sk 


\section{Abstract}

\section{THE ANALYSIS OF EXPORT TRADE BETWEEN UKRAINE AND VISEGRAD COUNTRIES}

\section{Ludmila Nagyová, Monika Horáková, Serhiy Moroz, Elena Horská, Zuzana Poláková}

The dynamic development of foreign trade is important for the stable economic position. It can be considered as a confirmation of the actual efficiency of the national economy and its ability to be competitive in the global economics. In this paper, we analyze main tendencies of export trade of Ukraine with Visegrad countries and examine whether there is a relationship between the level of GDP and the volume of export activities between these countries.

It should be noted that various agreements were concluded between Ukraine and each country of the V4 group regarding economic and trade relations.

The main aim of this paper is to evaluate development of export of goods between Ukraine and Visegrad countries between years 2002-2013. The data of State Statistics Service of Ukraine, Eurostat and United Nations Conference on Trade and Development (UNCTAD) were used.

The development of export from Ukraine to V4 countries is investigated using the software GRETL and log-log linear model.

It is discovered that Ukraine's export operations are impacted by export to other trade partners and GDP per capita of the country. The strongest positive link to Ukraine export from V4 group is represented by Poland. It is identified that, when the GDP per capita of the concerned country goes up, the export to that country declines. It is also revealed that there is a substantial difference with respect to export of agricultural commodities from Ukraine to the above-mentioned countries. To a significant extent, Ukraine's export is oriented towards plant products.

Ukraine should elaborate a well-defined trade strategy and extend its current export activities with V4 countries. It should be more deeply integrated into the EU's market for using more efficiently possibilities, which exist in the frame of the signed Ukraine-European Union Association Agreement.

Key Words: Export of goods, trade development, Ukraine, Visegrad countries.

JEL Classification: F1.

DOI: 10.15240/tul/001/2018-2-008 